NIKOLA MILIĆEVIĆ, Ph.D. ${ }^{1}$

E-mail: milicevic.nikola@ef.uns.ac.rs

ALEKSANDAR GRUBOR, Ph.D. ${ }^{1}$

E-mail: agrubor@ef.uns.ac.rs

NENAD ĐOKIĆ, Ph.D. ${ }^{1}$

(Corresponding author)

E-mail: djokicn@ef.uns.ac.rs

GORAN AVLIJAŠ, Ph.D. ${ }^{2}$

E-mail: gavlijas@singidunum.ac.rs

${ }^{1}$ University of Novi Sad, Faculty of Economics in Subotica

9-11 Segedinski put, 24000 Subotica, Serbia

2 Singidunum University

32 Danijelova St., 11000 Belgrade, Serbia
Transport Logistics

Review

Submitted: 17 Feb. 2017

Accepted: 11 Oct. 2017

\title{
RETAIL OUT-OF-STOCKS IN THE CONTEXT OF CENTRALIZED AND DIRECT DELIVERY
}

\begin{abstract}
The delivery of the right product, at the right time to the retail store, only seems to be an easy process. The smallest problem can cause the out-of-stock (OOS) situation, which may prevent customers to buy products they were looking for. Consequently, it affects retailers and their suppliers through potential operational inefficiencies, sale losses and eventually the losses of their loyal customers. Starting from these problems, by using the data of a large Serbian retailer, this paper analyses out-of-stocks in the context of two alternative delivery systems, centralized and direct. For calculat ing OOS rates the perpetual inventory aggregation metrics was used, while the occurrence of out-of-stocks was modelled by the application of probit regression analysis. The results have shown that delivery system has a significant impact on the probability of a stock-out, indicating potential problems in the centralized system. In addition, the analysis included certain product and store characteristics that also significantly affect the average probability of stock-outs.
\end{abstract}

\section{KEY WORDS}

out-of-stock; centralized delivery; direct delivery; retail; probit regression;

\section{INTRODUCTION}

In retail sector logistics is usually related to providing adequate product availability level, i.e. to delivering the right product, at the right time, to the right place. According to Fernie and Sparks [1], this description does not reflect the real amount of effort that has to be invested into logistics supply system and the multitude of ways that supply systems can go wrong (p. 3). Moreover, it represents logistics as an easy process.

In practice, it is much more different. Significant efforts and monetary resources are spent on keeping the products continuously available to customers [2].
Nevertheless, they are often confronted with the situation in which the desired product is not available in the store. That situation, known as out-of-stock, produces problems for all supply chain members.

Corsten and Gruen [3] found the average worldwide OOS rate of $8.3 \%$.In Europe, the out-of-stock rate was $8.6 \%$, whereby it varied across regions [3]. While Northwest Europe had the lowest, Southeast Europe showed the highest out-of-stock levels. According to Aastrup and Kotzab [4], the average o0S level at about 7 to $8 \%$ has not changed a lot, despite forty years of research.

For customers, the presented oos rate means that one out of every twelve items on their shopping list is out-of-stock [5]. Following Green [6], even with availability levels in the mid to high 90s, the probability of purchasing one item in each of the twelve categories without OOS, is less than $60 \%$. Thereby, the out-ofstock has been identified as one of the most important issues for customers, which decreases their consumption benefit [7]. It directly affects their behaviour [8] and may result in substitution, transaction and opportunity costs [9].

Out-of-stock has potentially negative implications for retailers and manufacturers [10], mostly depending on oos reactions. When a customer decides to switch the store, cancel the purchase or substitute the OOS item with the cheaper one, the retailer is confronted with sales losses. On the other hand, purchase cancellation and brand switch can result in manufacturer's sales decrease. Corsten and Gruen [3] estimated the overall sales losses at $3.7 \%-4 \%$. In addition, the decrease in store and/or brand loyalty, customer dissatisfaction and logistics inefficiencies can also occur as implications of out-of-stocks $[3,11]$. 
The causes for stock-outs may appear along the entire retail supply chain, whereby the significant number of them refers to downstream problems [12]. Therefore, in order to minimize negative consequences of out-of-stocks, attention should be dedicated to the whole product flow, from supplier to the retail store. In this regard, the products can be transported to stores directly by suppliers, or through retailers' distribution centres, i.e. the delivery process can be decentralized or centralized.

Bearing in mind that product availability represents the main task of the delivery process, the aim of this paper is to examine its complement, the out-of-stock, from the aspect of direct (decentralized) and indirect (centralized) system. Also, in addition to previous studies whose results were rather contradictory, for a better understanding of this issue, the research extended to certain product and store characteristics and their interaction terms as well. According to the authors' knowledge, this is the first study that included delivery system, product and store variables, and modelled them with the use of probit regression analysis. Hereby, the out-of-stock, as the dependent variable, occurs when a certain product is not present on a certain day in a certain store.

The paper consists of six sections. Section 2 presents basic characteristics of two delivery systems. Section 3 considers out-of-stocks and variables that affect them, with the special emphasis on studies related to delivery systems. Section 4 refers to the methodology used in this paper. Section 5 presents the results, followed by discussion and conclusions in Section 6 .

\section{DELIVERY SYSTEMS IN RETAIL}

In the last few decades, there have been many changes in marketing channels that have led to a shift in the balance of power from manufacturers to retailers [13]. Through organic growth, mergers and acquisitions, large retail companies have developed extensive store networks with incomes that are measured in tens of billions of euro. In Germany, Austria, the United Kingdom and France, the market share of top three grocery retailers amounts to $60.2 \%, 78.5 \%$, $55 \%$ and $48.5 \%$, respectively $[14,15]$. In addition to high concentration, the presence of trade allowances and slotting fees, growing importance of private labels and the use of modern information (scanner) technology have also supported the dominant retail power position [16].

Major changes have also occurred in the logistics sector, i.e. in the way in which products have been delivered to retail stores [17]. Retailers used their higher market concentration to take control over product flows from the suppliers [18], evolving from passive recipients to active supply chain designers [1]. This transformation in retail logistics can be manifested through six closely inter-related trends [19]:

- Increasing retailers' control over secondary distribution by centralizing supplies through distribution centres (DCs);

- Restructuring of retailers' logistical systems to reduce inventory and generally improve their efficiency through the development of "composite distribution" and centralization of slower-moving stock;

- Adoption of "Quick Response" with the aim of cutting inventory levels, reducing order lead times and moving to a more frequent delivery of smaller consignments both internally (between DC and store) and on external links with suppliers;

- Rationalization of primary distribution(i.e. factory to warehouse) and its integration with secondary distribution operations into a single "network system";

- Introduction of Supply Chain Management (SCM) and Efficient Consumer Response (ECR) which can provide a management framework for effective coordination of retail supply chain as a whole;

- Increasing retailers' involvement in "reverse logistics" operations (p. 2).

In changed logistics network, grocery retailers usually operate distribution centres through which they channel a significant proportion of their supplies [20]. This system allows retailers to bundle products across many suppliers and to reduce truck arrivals at the store [21, p. 205]. They can use one or more distribution centres (central or regional) in which the following activities are often performed [22]:

- Coordinating inbound transportation;

- Receiving, checking, storing and cross-docking;

- Getting merchandise "floor-ready";

- Coordinating outbound transportation.

The level of centralization at large retail chains maintains from 50 to more than 90\% [23]. Thereby, while at leading grocery retailers in Germany, Austria and Switzerland it nearly exceeds $82 \%$ [20], in the United Kingdom it reaches almost 95\% [24]. In addition, the largest UK retailer, Tesco, has developed one of the most efficient networks of composite distribution centres in Europe [25]. Each DC is equipped with modern warehouse and information systems and serves more than 100 stores. Furthermore, the whole delivery process relies on close cooperation between Tesco and its suppliers, based on the constant exchange of POS data through "Tesco Information Exchange" platform.

Well established centralized delivery system can bring many benefits to retailers in terms of better negotiating position with suppliers, higher efficiency and improved customer control [17]. The realization of frequent deliveries with shorter lead times, organized through computer linkage with suppliers, decreases 


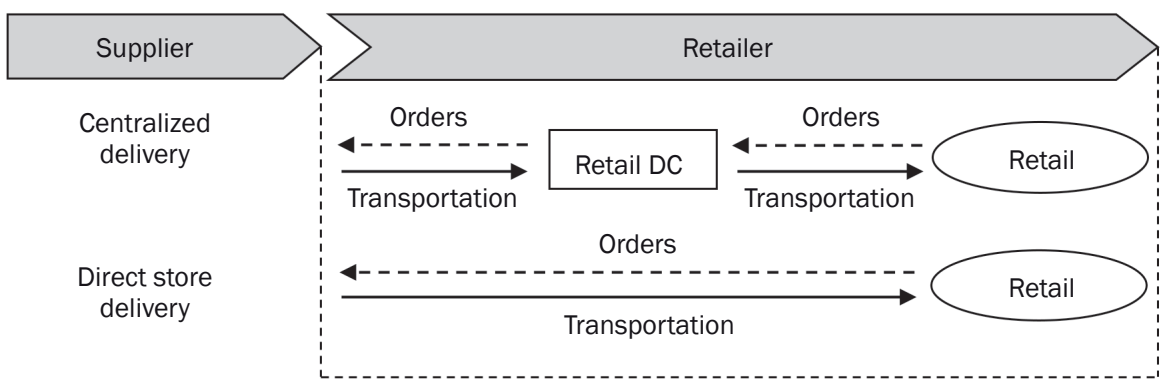

Figure 1 - Delivery systems in retail

inventory levels across the whole retail chain. However, if the ordering process for centralized deliveries depends on store personnel alone, this system may be exposed to lower order accuracy [23]. The implementation of the centralized system can also result in higher retailers' transportation and warehouse costs.

In addition to centralization, products can be delivered to stores directly from suppliers. In this case, the direct store delivery system (DSD) is applied. From retailers' aspect, DSD system refers to all store deliveries that bypass retailers' distribution centres [26]. It is primarily used for food, beverages and tobacco products, whereas in the United States it produces up to $30 \%$ of total retail sales volume of small- and large-format stores [27].

On an operational level, direct store delivery process can be divided into primary and secondary [28]. Primary DSD process, which relates to order fulfilment, includes the following sub-processes [27]:

- Order management - receiving customer sales orders via different channels;

- Tour preparation -activities that precede the physical distribution;

- Check out -additional checking after leaving the vehicles;

- Physical distribution - delivering products to customers;

- Check in - checking process after returning the vehicles;

- Route settlement - synchronizing planned and actual tour information.

Bearing in mind that DSD allows direct access to retail stores, suppliers can also perform certain activities on-site. These secondary processes include information gathering, placement, positioning, merchandising, payment collection, category management, equipment service and data synchronization [27].

The use of direct store delivery system can result in numerous advantages for retailers that mostly depend on the level of cooperation and information exchange with their suppliers. On the logistics area, it can provide higher order accuracy [23] and lower transportation, warehouse and inventory carrying costs [29]. DSD process can also bring benefits in sales and marketing, such as better product pricing, quicker shelf sensing, higher promotion and merchandising effectiveness [27, 30]. On the other hand, in addition to potential overstocking [29], longer lead time and lower order frequency [23], one of the problems of this delivery system for retailers may be the loss of control over replenishment process [29].

\section{OUT-OF-STOCKS AND DELIVERY SYSTEMS}

Bearing in mind its negative effect on retail business performance, out-of-stock has been drawing the attention of scientific community for several decades. The OOS problem has been analysed from many aspects, including certain store and product characteristics.

In terms of the size, larger retail stores are associated to lower out-of-stocks due to better space conditions and formal employee hierarchy [31, 32]. Additionally, OOS rates may be related to the size of stores backroom storage areas as well [33, 34], which usually have a role of a safety buffer. Because of this, larger stores may be more appropriate for direct deliveries, especially for products with relatively long lifecycle. Moreover, if a retailer does not have adequate equipment for storing and transporting perishables, these products are also delivered directly from suppliers. On the other hand, smaller stores, often located in intercity cores, are prone to problems related to parking and traffic congestion. Hence, centralized delivery, including a number of different products, might be a more appropriate option for some of them.

Out-of-stock levels can also correlate with product sales indicators, such as sales frequency and sales variation. Thereby, because of the neglecting and forecasting difficulties, slow moving products, as those with high sales variations, are usually the most problematic from the availability aspect [33].

In addition to these variables, in a few studies, retail out-of-stock has been investigated from the delivery aspect. In this regard the emphasis was on two logistics systems, direct and centralized. 
According to Gruen and Corsten [34], centralized delivery system has an advantage in terms of product availability. Following them, higher out-of-stock levels for products delivered directly from the suppliers occur as a result of poor coordination between store and shelf replenishment operations, especially when external merchandisers or rack jobbers were engaged. In this case, the products were usually left in the backroom storage area, waiting to be put on a shelf.

The results of Pramatari and Miliotis [23] research, conducted in five stores of a large grocery retailer in Greece, have also shown that the overall out-of-stock level was lower at centralized compared to DSD products. Moreover, these authors pointed out that the main OOS causes for both delivery systems were related to "wrong order quantity" and "no order" problems.

However, opposite to previous research, in certain studies $[27,30]$ the advantage is on the side of DSD. For example, Otto et al. [27] argue that direct store delivery lowers out-of-stocks, indicating that DSD products have higher availability levels than the average worldwide $00 \mathrm{~S}$ rate of $8.3 \%$. In addition, the study conducted by Grocery Manufacturers Association, AMR Research, Clarkston Consulting and Nielsen Company [30] has shown that the reduction of out-of-stocks represents the most important future vision of DSD power for retailers.

Furthermore, besides studies which favour one of the systems, the difference in availability levels between direct and centralized delivery does not have to be significant at all. Following Roland Berger Consultants [7] survey, the delivery systems are not so important with regard to product availability, whereas the difference in out-of-stock levels between them was lower than $0.3 \%$. Similar to them, marginal difference in product availability between these systems was also found by Andersen Consulting [35] in a study commissioned by Coca-Cola Retailing Research Council.

\section{RESEARCH METHODOLOGY}

Starting from different results of presented studies, we have analysed retail out-of-stocks in the context of centralized and direct delivery system. Besides this relation, our model included certain store and product characteristics and their interactions with the delivery system, as well (Figure 2).

For this analysis, we used data from a single grocery retailer, which ranks among top 5 retailers in the Republic of Serbia. With the help of its logistics director, we have selected 60 different products from CPG (consumer packaged goods) category, including both delivery systems. Daily sales and inventory data for all sampled products have been taken from 20 retail stores for the period March-July 2014. Thereby, our dataset consisted of more than 180,000 observations (20 stores - 60 products - 153 days).

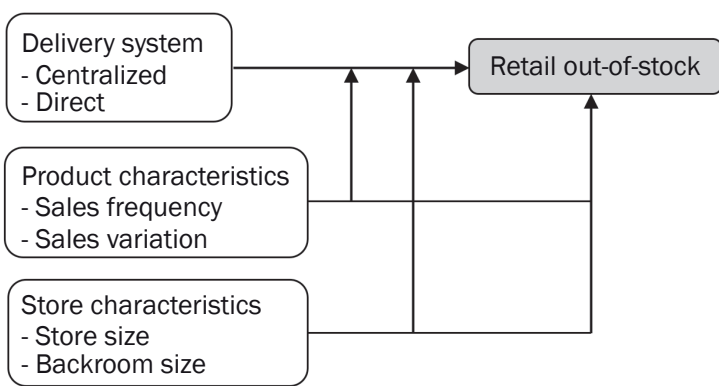

Figure 2 - Conceptual model

For calculating out-of-stock rates for each product in each store, we relied on perpetual inventory aggregation metrics. Beside this method, physical counting can also be applied. However, bearing in mind that the focus of this research is on retailer and its upstream supply chain, the choice was on the first method. In this way, the 00S rate represents the percentage of the maximum possible product availability:

OOSrate $=$

$$
=\frac{\sum_{i}^{n} \sum_{j}^{m} \sum_{k}^{l} \text { stockout }_{i j k}}{\sum_{i}^{n} \sum_{j}^{m} \sum_{k}^{l} \text { maximum product availability } i j k}
$$

where:

$i$ - product for which the OOS rate is measured,

$n$ - total number of products,

$j$ - store for which the OOS rate is measured,

$m$ - total number of stores,

$k$ - the first day,

$l$ - the last day.

If there is a stock-out of a certain product on a certain day in a certain store, the dependent variable (out-of-stock) will have value 1 . On the contrary, when there is at least one product in stock, it will have value 0 . The out-of-stock for any product $(i)$ - store $(j)$-time $(k)$ combination was analysed as the function of:

$$
\begin{gathered}
\text { OOS }_{i j k}=f(\text { delivery system, } \text { product variables, } \\
\text { store variables })
\end{gathered}
$$

As presented in Figure 2, product variables include sales frequency and sales variation, while store variables are store size and backroom size. The operationalization of all variables is listed in Table 1.

Bearing in mind that the dependent variable is binary, for modelling the occurrence of out-of-stocks, both probit regression and logistic regression can be applied. The choice between two models was based on comparison of their relative quality. For this purpose, two measures of model fit were used: the Bayesian information criterion (BIC) and Akaike information criterion (AIC). Lower values of those two measures in the case of probit regression ( $\mathrm{AIC}=60,188.06$; $\mathrm{BIC}=60,248.78)$ in comparison to logistic regression 
Table 1 - Research variables

\begin{tabular}{||l|l|l||}
\hline \multicolumn{2}{|l|}{ Variables } & \multicolumn{1}{c||}{ Operationalization } \\
\hline \hline Stock-out & OOS occurrence & stock-out $=1$, no stock-out $=0$ \\
\hline Delivery & Delivery systems & direct $=1$, centralized $=0$ \\
\hline \multirow{3}{*}{ Product } & Sales frequency & speed of turnover (average sales per day) \\
\cline { 2 - 4 } & Sales variation & coefficient of variation (ratio of standard deviation and average sale) \\
\hline \multirow{3}{*}{ Store } & Store size & sales area \\
\cline { 2 - 3 } & Backroom size & ratio of backroom size and sales area $(\%)$ \\
\hline
\end{tabular}

( $\mathrm{AIC}=60,338.68 ; \mathrm{BIC}=60,399.40)$ indicated that the first model had a better fit. Because of this, we have selected probit regression. Although normality of distribution is regarded as precondition of implementing probit model, the number of observations, in the context of the central limit theorem, allowed the use of probit model within this research.

Most data necessary for computing variables have been taken from retailer's information system and its management. This involves daily sales and inventory reports for all selected products and retail stores, primarily used for deriving out-of-stocks, sales frequencies and sales variations. For data preparation and analysis, statistical software Stata 13 was used.

\section{RESULTS}

After the application of perpetual inventory aggregation approach, the out-of-stock rate was calculated. As shown in Table 2, its average level amounts to $4.44 \%$.

Table 2 - Descriptive statistics

\begin{tabular}{||l|c|c|c|c|c||}
\hline \multicolumn{1}{|c|}{ Variables } & Obs. & Mean & Std. Dev. & Min & Max \\
\hline \hline OOS & 183,600 & 0.0444063 & 0.2059967 & 0 & 1 \\
\hline Delivery system & 183,600 & 0.5 & 0.5000014 & 0 & 1 \\
\hline Sales frequency & 183,600 & 13.86652 & 25.5356 & 0.010929 & 248.4699 \\
\hline Sales variation & 183,600 & 1.607033 & 1.25846 & 0.274707 & 11.64652 \\
\hline Store size & 183,600 & $1,016.379$ & 645.3127 & 250 & 2,300 \\
\hline Backroom size & 183,600 & 35.39735 & 7.96955 & 15.23652 & 48.57638 \\
\hline
\end{tabular}

Table 3 - Probit model

\begin{tabular}{||l|c|c|c|c|cc||}
\hline \multicolumn{1}{|c|}{ Variables } & Coef. & Std. Err. & $z$ & $P>|z|$ & \multicolumn{2}{c||}{ [95\% Conf. Interval] } \\
\hline \hline Delivery system & -0.0800276 & 0.0112613 & -7.11 & 0.000 & -0.1020993 & -0.0579559 \\
\hline Sales frequency & -0.0016537 & 0.0002591 & -6.38 & 0.000 & -0.0021616 & -0.0011459 \\
\hline Sales variation & 0.2161142 & 0.0031556 & 68.48 & 0.000 & 0.2099293 & 0.2222992 \\
\hline Store size & -0.0002263 & $9.55 \mathrm{e}-06$ & -23.70 & 0.000 & -0.000245 & -0.0002076 \\
\hline Backroom size & -0.0073605 & 0.0006161 & -11.95 & 0.000 & -0.008568 & -0.006153 \\
\hline Cons & -1.610164 & 0.0241213 & -66.75 & 0.000 & -1.657441 & -1.562887 \\
\hline \hline
\end{tabular}

Note: Number of obs.=183,600; Log likelihood=-30,088.029; $L R \chi^{2}(5)=6,545.39 ;$ Prob $>\chi^{2}=0.000 ;$ Pseudo $R^{2}=0.0981$

Probit model, which includes delivery system and both product and store characteristics as independent variables, is presented in Table 3. Model's Log likelihood value, used in the Likelihood Ratio ChiSquare test, is $-30,088.029$. The probability of obtaining the chi-square statistic $(6,545.39)$ if there is no effect on the dependent variable, is lower than 0.01 (Prob $>\chi^{2}=0.000$ ), confirming the statistical significance of the overall model. In addition, all model coefficients are statistically significant with $p<0.01$, as well.

In further analysis, for measuring the average predicted probability of an out-of-stock in terms of the regressors, the concept of marginal effects was used. Concerning the delivery system, which is a dichotomous variable, the marginal effect represents the difference in the predictions for the two groups, centralized and direct system (Table 4).

The average probability of an out-of-stock in the case of direct delivery $(0.040)$ is about $16 \%$ lower than the probability in the case of centralized delivery (0.047). Since the likelihood of a stock-out decreases 
Table 4 - Marginal effects for the delivery system

\begin{tabular}{||c|l|c|c|c|c|cc||}
\hline \multicolumn{2}{|c|}{ Variable } & Margin & Std. Err. & $z$ & $P>|z|$ & {$[95 \%$ Conf. Interval] } \\
\hline \hline \multirow{3}{*}{ Delivery system } & 0 (centralized) & 0.0474176 & 0.0006581 & 72.05 & 0.000 & 0.0461277 & 0.0487075 \\
\cline { 2 - 9 } & 1 (direct) & 0.0406441 & 0.0006709 & 60.58 & 0.000 & 0.0393292 & 0.041959 \\
\cline { 2 - 9 } & $d y / d x$ & -0.0067735 & 0.0009512 & -7.12 & 0.000 & -0.0086379 & -0.0049091 \\
\hline
\end{tabular}

with the change from centralized to direct delivery, it can be concluded that delivery system has a significant effect on the probability of an out-of-stock. Marginal effects for other independent variables are presented in Table 5.

While sales frequency has a negative impact on the probability of a stock-out, another sales indicator, sales variation, positively affects the probability of an out-of-stock. On the other hand, both store characteristics (store size and backroom size) have a negative impact on the probability of an OOS. Bearing in mind that all these variables are continuous, predicted probabilities of a stock-out have been estimated for ranges of their different values.

Figure 3 presents marginal effects for sales frequency including alternative delivery systems. As can be seen, with the decrease of sales frequency, the average probability of an out-of-stock increases. For example, the average probability of an out-of-stock for average sales of 250 is lower than 0.02 , while for average sales of 1 it is more than twice as high (0.045). This change in predicted probability occurs at both delivery systems, whereby the average probability levels are significantly lower in the case of direct delivery.
Opposite to sales frequency, with the increase of sales variation, the predicted probability of a stock-out increases as well. For the coefficient of sales variation of 1 , the average probability of an out-of-stock is 0.027 , which is almost 25 times lower than the O0S probability for coefficient of variation of 12 (0.663). As presented in Figure 4, sales variation increases the average probability of a stock-out at both centralized and direct delivery system. Hereby, the average probability of a stock-out is higher in the case of centralized delivery at all levels of sales variation.

Concerning store variables, store size and backroom size decrease the average probability of stockouts. When store size increases from 250 to 2,300 square meters, the predicted probability of an out-ofstock decreases for more than 60\%, from 0.058 to 0.023 (Figure 5).

A similar relation holds for the backroom size. The average probability of OOS decreases for almost 40\% when the ratio of backroom size and sales area increases from 15 to 49\% (Figure 6). Reductions in predicted probabilities of stock-outs due to the increase of store and backroom size appear at both delivery systems. Moreover, as in the case of product variables, significantly lower OOS probability levels are related to DSD system.

Table 5 - Marginal effects for product and store characteristics

\begin{tabular}{||l|c|c|c|c|cc||}
\hline \multicolumn{1}{|c|}{ Variables } & $d y / d x$ & Std. Err. & $z$ & $P>|z|$ & {$[95 \%$ Conf. Interval] } \\
\hline \hline Sales frequency & -0.0001403 & 0.000022 & -6.37 & 0.000 & -0.0001835 & -0.0000972 \\
\hline Sales variation & 0.0183373 & 0.0002857 & 64.19 & 0.000 & 0.0177774 & 0.0188972 \\
\hline Store size & -0.0000192 & $8.22 \mathrm{e}-07$ & -23.37 & 0.000 & -0.0000208 & -0.0000176 \\
\hline Backroom size & -0.0006245 & 0.0000525 & -11.91 & 0.000 & -0.0007274 & -0.0005217 \\
\hline
\end{tabular}
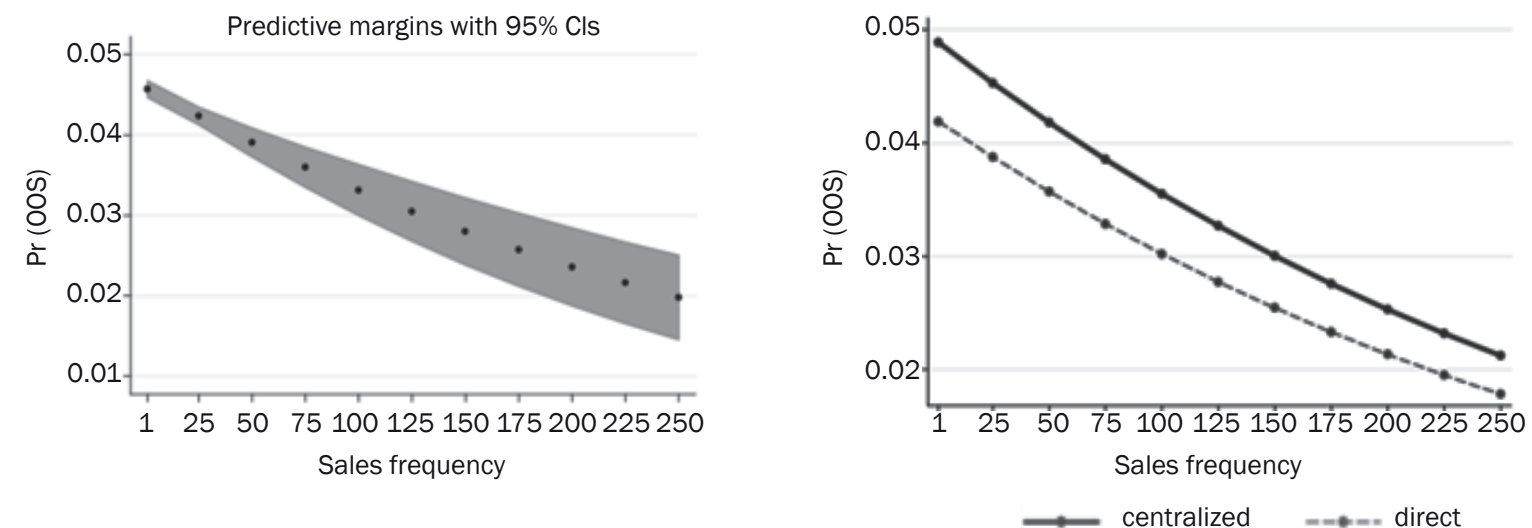

Figure 3 - Marginal effects for sales frequency 

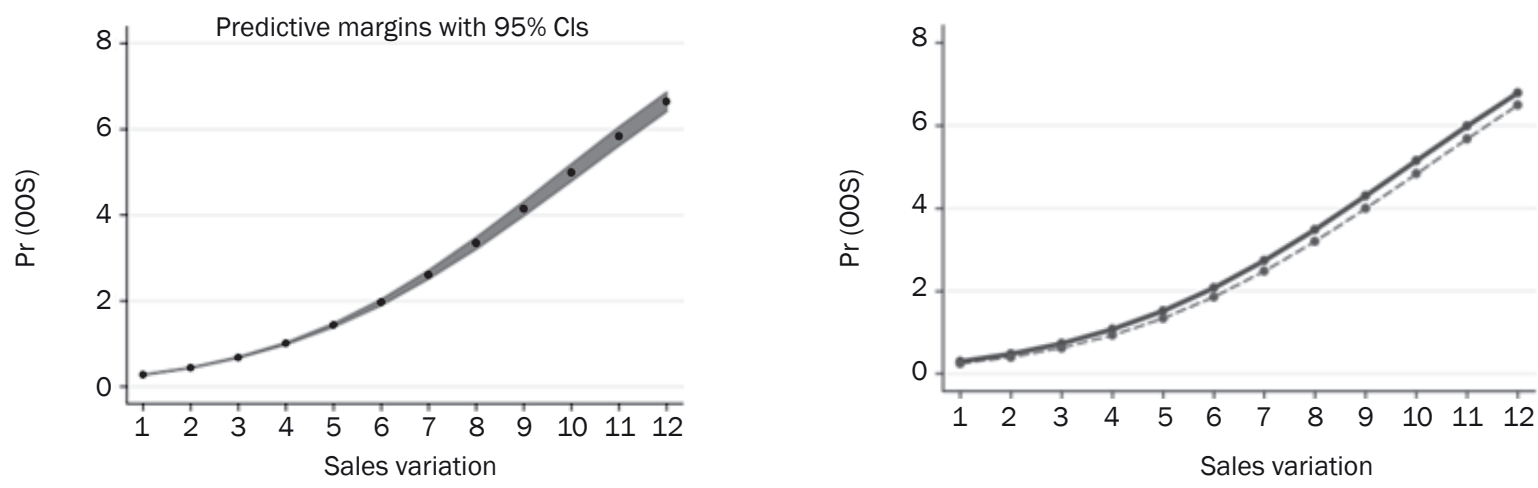

$\longrightarrow$ centralized $\quad=-\cdots$ direct

Figure 4 - Marginal effects for sales variation
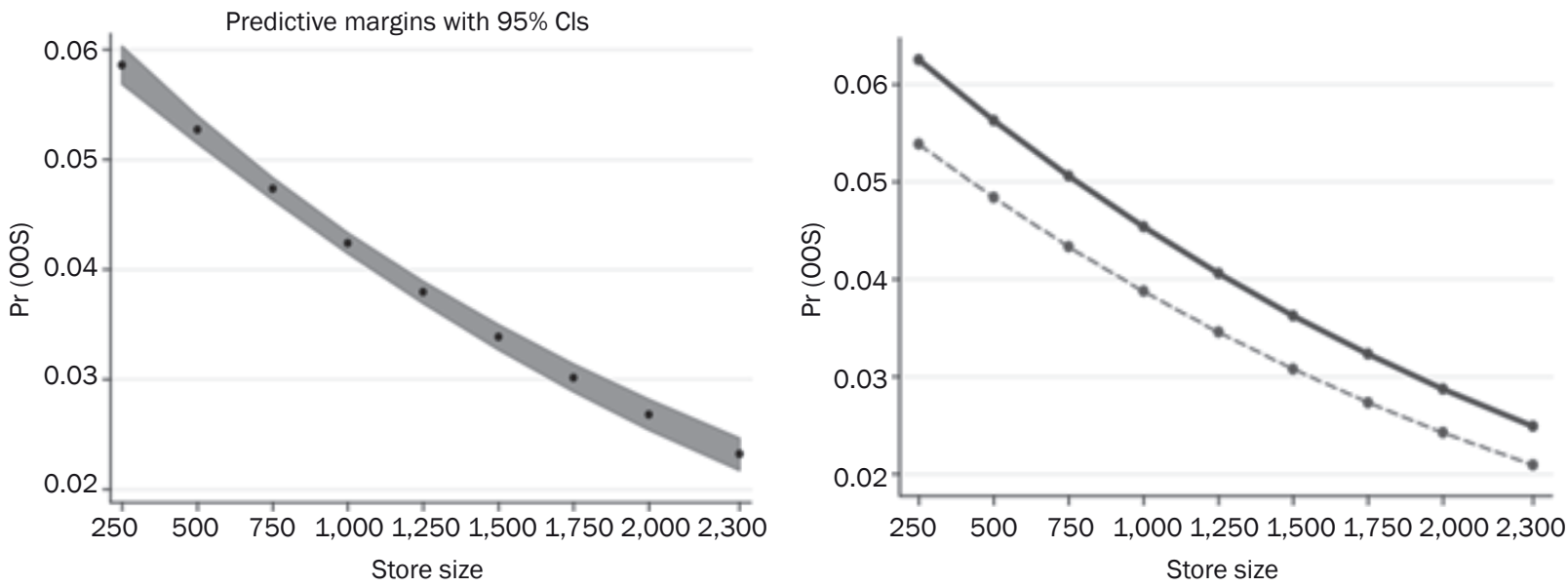

Figure 5 - Marginal effects for store size
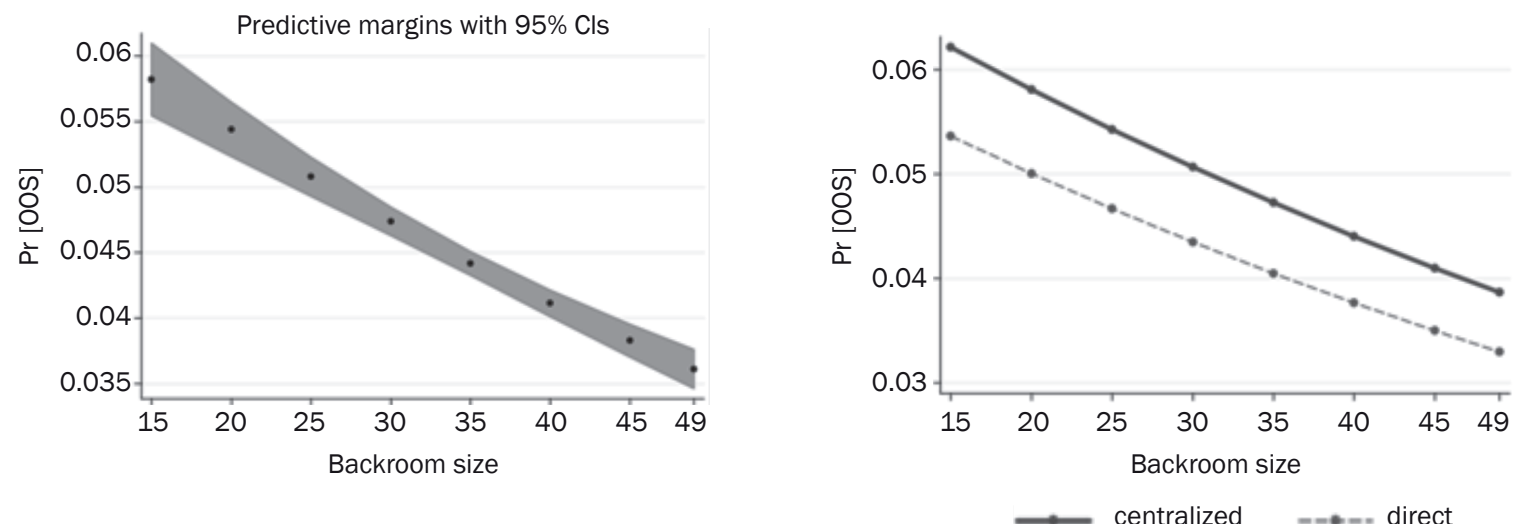

Figure 6 - Marginal effects for backroom size

\section{DISCUSSION}

When considering the delivery system, the results have shown that this variable had a significant impact on the probability of a stock-out. Thereby, the average oos probability was much higher in the case of centralized, compared to direct delivery system. The advantage of DSD system in terms of product availability may be the result of potential problems and inefficiencies in retailer's DC followed by larger suppliers' investments into logistics activities. The identified problems can be observed in the context of the overall trade logistics performance in Serbia. According to the LPI (Logistic Performance Index) global ranking, the 
Republic of Serbia lags behind most European countries [36]. Although there are some differences in certain LPI key dimensions' rankings, the previous conclusion refers to all of them - customs, infrastructure, international shipments, logistics quality and competence, tracking and tracing as well as timeliness.

Contrary to the world's leading retailers whose DCs cover tens of thousands of square meters, domestic chains usually use smaller, poorly equipped distribution (warehouse) centres. In the lack of sophisticated warehouse management systems, conveyor networks, contemporary identification (RFID) and picking technologies (such as pick-to-light and/or pick-to-voice solutions), most operations are performed manually, leaving a lot of room for errors. On the other hand, their suppliers(usually distributors) are trying to keep pace with new trends in the logistics sector. In a struggle for a place on the shelf, they have invested in storage and transportation capacities, adapted to their offers (products). This has enabled them to deliver different amounts of products directly to stores in a much more efficient way. Moreover, in the case of DSD system, suppliers' salespersons often participate in the ordering processes as well [23]. Their better market knowledge about products that they represent can be of great help for store personnel in preparing the orders. What is more, it is not uncommon for authorized salespersons to suggest larger quantities of products in order to increase the sale and ensure their availability in stores.

When considering product and store variables, the attention was dedicated to sales frequency, sales variation, store size and backroom size. From the availability aspect, slow turning and products with high sales variations were critical. While the former may be neglected by retailer's employees due to infrequent orders [35], the latter may be confronted with forecasting difficulties, which according to several studies $[7,37]$, represent one of the main O0S causes. In the context of retail stores, their size, as well as the size of their backrooms, had a negative effect on the average probability of an out-of-stock. The advantages of larger space are reflected in better allocation possibilities and more facings to products [32]. Also, larger stores usually have a more formal organization with a clear division of obligations and responsibilities [32], which can positively affect the availability levels. Furthermore, the interactions between these variables and the delivery system have shown that OoS probabilities for both systems had the same direction, whereby they were significantly higher in the case of centralized delivery.

Bearing in mind that the out-of-stock problem was much more common in the centralized system, in order to increase availability levels, the attention should be dedicated to its improvement. Higher efficiency of centralized delivery can be achieved through investments in capacities and equipment of distribution centres. Even though it is very costly, it can bring significant benefits in the long run. For example, the application of RFID technology in retail stores can increase business efficiency in regard to total costs and service levels [38]. Thereby, besides RFID tagging of expensive products, the tagging of the ones which are even cheaper than an RFID tag can also have positive effects on retailers' business performance [39]. Moreover, concerning competition, certain European retail chains that operate on the Serbian market have already had large investments into logistics sector for the last few years.

Along with the investments in own resources, the cooperation between retailers and their suppliers is also of great importance for minimizing out-of-stocks in both, centralized and DSD systems [23]. Bearing in mind that ordering and forecasting practices are responsible for a large percentage of OOS [7, 37], certain collaborative business models, such as vendor-managed inventory (VMI) and collaborative planning forecasting replenishment (CPFR), can be implemented. The information obtained from suppliers can be useful to retailers in space allocation and assortment planning operations as well, especially for smaller stores, as for those with limited backroom areas.

\section{CONCLUSION}

Despite the development and significant investments, especially in logistics activities, retail companies are still facing with an out-of-stock problem. Not only that this situation may result in the loss of their sales, but eventually it may lead to the loss of loyal customers as well. Hence, the OOS problem has been analysed from several aspects in order to identify its main factors of influence. In this paper, the out-ofstock was examined in the context of delivery system, product and store characteristics. Thereby, to the authors' knowledge, this is the first study that included the mentioned variables, their interactions, and modelled them with the use of probit regression analysis.

The results of the research have shown that the average OOS probability was much higher in the case of centralized in comparison to direct delivery system. In addition, in terms of product availability, slow turning and products with high sales variations were critical. Finally, the store size and the size of its backroom negatively affected the probability of an out-of-stock.

Within the paper, the discussion regarding the obtained results, as well as recommendations for practitioners was provided. In the future studies, the relations between out-of-stocks and delivery systems should be quantified in terms of their costs. Thus, the out-of-stock can be used as an important indicator for organizing store deliveries. In addition, future studies should include other products and product character- 
istics, such as package size, life cycle, price, etc. The inclusion of these variables could yield results that would be of additional importance for managerial implications.

\section{Dr NIKOLA MILIĆEVIĆ ${ }^{1}$}

E-mail: milicevic.nikola@ef.uns.ac.rs

Dr ALEKSANDAR GRUBOR ${ }^{1}$

E-mail: agrubor@ef.uns.ac.rs

Dr NENAD ĐOKIĆ ${ }^{1}$

(Dopisni autor)

E-mail: djokicn@ef.uns.ac.rs

Dr GORAN AVLIJAŠ ${ }^{2}$

E-mail: gavlijas@singidunum.ac.rs

1 Univerzitet u Novom Sadu, Ekonomski fakultet u Subotic Segedinski put 9-11, 24000 Subotica, Republika Srbija

2 Univerzitet Singidunum

Danijelova ulica 32, 11000 Beograd, Republika Srbija

\section{NEDOSTATAK ZALIHA U MALOPRODAJI U KONTEKSTU CENTRALIZOVANE I DIREKTNE ISPORUKE}

\begin{abstract}
APSTRAKT
Isporuka pravog proizvoda, u pravom trenutku u maloprodajni objekat, samo izgleda da je jednostavan proces. najmanji problem može prouzrokovati situaciju nedostatka zaliha, koja može sprečiti kupce da kupe željene proizvode. Shodno tome, data situacija utiče na maloprodavce i njihove dobavljače kroz potencijalne operativne neefikasnosti, gubitke u prodaji i na kraju gubitke lojalnih kupaca. Polazeći od ovih problema, koristeći podatke velike maloprodajne kompanije iz Srbije, ovaj rad analizira nedostatak zaliha u kontekstu dva alternativna sistema isporuke, centralizovanog i direktnog. Za izračunavanje stopa nedostatka zaliha korišćena je perpetualna metoda agregacije zaliha, dok je pojavljivanje nedostatka zaliha modelovano primenom probit regresione analize. Rezultati su pokazali da sistem isporuke značajno utiče na verovatnoću pojave nedostatka zaliha, ukazujući na potencijalne probleme u centralizovanom sistemu. Pored toga, analiza uključuje i određene karakteristike proizvoda i objekata koje značajno utiču na prosečnu verovatnoću pojave nedostatka zaliha.
\end{abstract}

\section{KLUUČNE REČI}

nedostatak zaliha; centralizovana isporuka; direktna isporuka; maloprodaja; probit regresija;

\section{REFERENCES}

[1] Fernie J, Sparks L, editors. Logistics and retail management: emerging issues and new challenges in the retail supply chain. $4^{\text {th }}$ ed. London: Kogan Page; 2014.

2] Steinhart Y, Mazursky D, Kamins MA. The process by which product availability triggers purchase. Marketing Letters. 2013; 24(3): 217-228. doi: 10.1007/s11002013-9227-4

[3] Corsten D, Gruen T. On shelf availability: An examination of the extent, the causes, and the efforts to address retail out-of-stocks. In: Doukidis GJ, Vrechopoulos AP, editors. Consumer Driven Electronic
Transformation. Berlin: Springer; 2005. p. 131-149.

[4] Aastrup J, Kotzab H. Forty years of out-of-Stock research and shelves are still empty. The International Review of Retail. Distribution and Consumer Research. 2010; 20(1): 147-164. doi: 10.1080/09593960903498284

[5] FMI, GMA. Solving the out-of-stock problem: A FMI/ GMA Trading Partner Alliance Report. Denver, 2015.

[6] Green M. Availability on the shelf: last great challenge for retail. Logistics \& Transport Focus. 2004;6:22-27.

[7] Roland Berger Consultants. ECR - Optimal Shelf Availability: increasing shopper satisfaction at the moment of truth. Munich: Roland Berger Consultants, 2003.

[8] Ku HH, Kuo CC, Fang WL, Yu YW. The impact of retail out-of-stock options on preferences: the role of consumers' desire for assimilation versus differentiation. Marketing Letters. 2014;25(1): 53-66. doi: 10.1007/ s11002-013-9241-6

[9] Campo K, Gijsbrechts E, Nisol P. Towards understanding consumer response to stock-outs. Journal of Retailing. 2000; 76(2): 219-242. doi: 10.1016/S00224359(00)00026-9.

[10] Frontoni E, Mancini A, Zingaretti P, Contigiani M, Di Bello L, Placidi V. Design and test of a real time shelf out of stock detector system. Microsystem Technologies. 2016; 1-9. doi:10.1007/s00542-016-3003-3

[11] Grant DB, Fernie J. Research note: Exploring out-ofstock and on-shelf availability in non-grocery, high street retailing. International Journal of Retail \& Distribution Management. 2008; 36(8): 661-672. doi: 10.1108/09590550810883496

[12] Ehrenthal JCF, Stölzle W. An examination of the causes for retail stockouts. International Journal of Physical Distribution \& Logistics Management. 2013; 43(1): 54-69. doi: 10.1108/09600031311293255

[13] Lovreta S, Koncar J, Petkovic G. Marketing channels. Belgrade: Faculty of Economics Belgrade; 2006.

[14] Trautrims A, Grant DB, Schnedlitz P. In-store logistics processes in Austrian retail companies. European Retail Research. In: Morschett D, Foscht T, Rudolph T, Schnedlitz P, Schramm-Klein H, Swoboda B, editors. European Retail Research. Heidelberg: Gabler Verlag; 2011. p. 63-84.

[15] Planet Retail. European Grocery Retailing: change is the only constant. London: Planet Retail Limited; 2014.

[16] Amato LH, Amato $\mathrm{CH}$. Changing retail power and performance in distribution channels. International Journal of Retail \& Distribution Management. 2009; 37(12): 1057-1076. doi: 10.1108/09590550911005029

[17] Fernie J, McKinnon A. The impact of changes in retail distribution on a peripheral region: the case of Scotland. International Journal of Retail \& Distribution Management. 1991; 19(7): 25-32. doi: 10.1108/ EUM0000000002958

[18] Trautrims A. Management of In-store Replenishment Systems: An exploratory study of European retailers [PhD thesis]. Hull: The University of Hull; 2011. Available from: https://hydra.hull.ac.uk/assets/ hull:4697a/content

[19] McKinnon AC. The development of retail logistics in the UK: a position paper. Technology Foresight Programme: Retail and Distribution Panel. Edinburgh: Heriot-Watt University; 1996.

[20] Kuhn H, Sternbeck MG. Integrative retail logistics: An 
exploratory study. Operations Management Research. 2013; 6(1): 2-18. doi: 10.1007/s12063-012-0075-9

[21] Sternbeck MG, Kuhn H. An integrative approach to determine store delivery patterns in grocery retailing. Transportation Research Part E: Logistics and Transportation Review. 2014; 70: 205-224. doi: 10.1016/j. tre.2014.06.007

[22] Levy M, Weitz BA. Retailing Management. Irwin: McGraw-Hill; 2012

[23] Pramatari K, Miliotis P. The impact of collaborative store ordering on shelf availability. Supply ChainManagement: An International Journal. 2008; 13(1): 4961. doi: $10.1108 / 13598540810850319$

[24] Kaipia, R, Tanskanen K. Vendor managed category management - an outsourcing solution inretailing. Journal of Purchasing and Supply Management. 2003; 9(4): 165-75. doi: 10.1016/S1478-4092(03)00009-8

[25] Harrison A, Van Hoek R. Logistics Management and Strategy: Competing through the Supply Chain. $3^{\text {rd }}$ ed. London: Prentice Hall; 2008.

[26] Wulfraat M. Direct store delivery versus centralized distribution. MWPVL; 2016. Available from:http://www. mwpvl.com/html/dsd_vs_central_distribution.html.

[27] Otto A, Schoppengerd FJ, Shariatmadari R, editors. Direct Store Delivery. Berlin: Springer-Verlag; 2009.

[28] Otto A, Shariatmadari R. Direct Store Delivery: Understanding DSD in Sales and Logistics, Results of the "Global DSD Analysis". Regensburg: University of Regensburg; 2008.

[29] Dujak D. Retail supply chain management through centralized distribution. Business Logistics in Modern Management [Internet]. 2012. Available from: http://www. efos.unios.hr/repec/osi/bulimm/PDF/BusinessLogisticsinModernManagement12/blimm1203.pdf

[30] Grocery Manufacturers Association, AMR Research, Clarkston Consulting, Nielsen Company. Powering Growth through Direct Store Delivery. Washington: The GMA DSD Committee; 2008.

[31] Fernie J, Grant DB. On-shelf availability: the case of a UK grocery retailer. The International Journal of Logistics Management. 2008;19(3): 293-308. doi: 10.1108/09574090810919170

[32] Aastrup J, Kotzab H. Analyzing out-of-stock in independent grocery stores: an empiricalStudy. International Journal of Retail \& Distribution Management. 2009; 37(9): 765-789. doi: 10.1108/09590550910975817

[33] Angerer A. The Impact of Automatic Store Replenishment Systems on Retail [PhD thesis]. St. Gallen: University of St. Gallen; 2005. Available from: http:// www1.unisg.ch/www/ edis.nsf/SysLkpByldentifier/3123/\$FILE/dis3123.pdf

[34] Gruen T, Corsten D. A Comprehensive Guide to Retail Out-of-Stock Reduction in the Fast-Moving Consumer Goods Industry. Colorado Springs: GMA, FMI, NACDS, P\&G, University of Colorado; 2007.

[35] Andersen Consulting. The retail problem of out-ofstock merchandise. Atlanta: Coca-Cola Retailing Research Council; 1996.

[36] Arvis J-F, Saslavsky D, Ojala L, Shepherd B, Busch C, Raj A. Connecting to Compete - Trade Logistics in the Global Economy: The Logistics Performance Index and Its Indicators. Washington: The World Bank; 2014.

[37] Corsten D, Gruen T. Desperately seeking shelf availability: an examination of the extent, the causes, and the efforts to address retail out-of-stocks. International Journal of Retail \& Distribution Management. 2003; 31(12):605-617. doi: 10.1108/09590550310507731

[38] Condea C, Thiesse F, Fleisch E. RFID-enabled shelf replenishment with backroom monitoring in retail stores. Decision Support Systems. 2012; 52(4): 839-849. doi: 10.1016/j.dss.2011.11.018

[39] Piramuthu S, Wochner S, Grunow M. Should retail stores also RFID-tag 'cheap' items? European Journal of Operational Research. 2014; 233(1): 281-291. doi: 10.1016/j.ejor.2013.08.051 